\title{
Online vs. Face-to-Face Lecture Courses: Factors Impacting the Effectiveness of Online Learning
}

\author{
Piyapong Janmaimool ${ }^{1, *}$ and Siriphan Nunsunanon ${ }^{1}$
}

1 Department of Social Sciences and Humanities, School of Liberal Arts, King Mongkut's University of Technology Thonburi, 126 Prachauthit Road, Thungkru District, Bangkok 10140

* Correspondence: piyapong.jan@kmutt.ac.th

\begin{abstract}
During the COVID-19 outbreak, most university courses have been offered on online platforms. A sudden shift from face-to-face classroom learning to online formats could influence the learning effectiveness of classes. This study aims to investigate differences in the learning effectiveness of online and face-to-face lecture courses. It also explores factors that impact the effectiveness of online instruction. These factors include interactions among learners, interactions between learners and the instructor, the quality of online platforms, learners' ability to use devices and follow instructions, and learners' situational challenges. The study participants were 261 university students at King Mongkut's University of Technology Thonburi in Bangkok, Thailand. All participants were enrolled in at least one lecture course, such as history, humans and the environment, the environment and development, or general philosophy, during the 2019 academic year. A questionnaire was distributed to participants after they completed these courses in May 2020. Paired simple t-test analyses were used to compare the effectiveness of online and face-to-face classes, and a multiple regression analysis was used to identify factors that impact the learning effectiveness of online classes. The results show that online classes are less effective than face-to-face courses. The multiple regression analysis also revealed that the effectiveness of online learning was significantly impacted by learners' ability to interact with classmates during class, their ability to interact with instructors after the class, the quality of online platforms, and disturbances or distractions in learners' environments.
\end{abstract}

Keywords: online learning, face-to-face learning, learning effectiveness, challenges with online learning, lecture-based courses.

\section{Introduction}

When the COVID-19 outbreak began in 2019 [1], most university courses shifted suddenly from face-to-face classrooms to online platforms, and both instructors and learners have faced diverse challenges related to learning and teaching [2-5]. In 2021, the COVID19 outbreak continues to impact learning and teaching activities at educational organizations, and many educational institutions have used online instruction from 2019 to 2021. Therefore, it is important to develop strategies for improving online instruction.

Many previous studies reveal the advantages of online learning for learners; most significantly, it is more flexible than face-to-face instruction [6]. Some studies [7,8] find that interactions between instructors and learners in online courses can be improved by the use of asynchronous and synchronous platforms such as Facebook, online forums and chats, and videoconferences. Additionally, online learning gives instructors better control over the content and time of teaching [9].

However, online learning may also have some disadvantages. It may negatively impact learners' motivation, and learners may feel isolated due to the lack of interaction with classmates [10]. However, these disadvantages can be overcome by changes to instructors' teaching strategies. Instructors' experience with and knowledge of online teaching could help them improve their teaching activities. Coman et al. [5] found that a sudden shift 
from face-to-face to online learning has many disadvantages. This is because both learners and instructors may lack experience with online learning and teaching and because appropriate learning and teaching environments may not be available. During the COVID19 outbreak, many instructors began to offer online instruction for the first time [11].

King Mongkut's University of Technology Thonburi in Bangkok, Thailand also followed this trend to avoid cancelling learning and teaching activities. Many lecture courses, such as history, humans and the environment, and general philosophy, shifted suddenly from face-to-face classrooms to online platforms. Many instructors are aware that a sudden change of learning platforms can negatively impact the learning process and that improvements to online learning are urgently needed.

This study aims to investigate differences in the learning effectiveness of online and face-to-face lecture courses. It also explores factors impacting the effectiveness of online instruction. These factors include interactions among learners; interactions between learners and the instructor; the quality of online platforms; learners' ability to use devices and follow instructions; and environmental challenges, such as software and hardware errors, disturbances or distractions in learners' environments, and learners' lack of active engagement in the learning process due to distraction.

\section{Literature Reviews}

\subsection{Learning Effectiveness}

Liu [12] defines learning effectiveness as a learner's acquisition of knowledge, skills, and attitudes through participation in a learning or training activity. From the perspective of students, learning effectiveness refers to learning values or outcomes that students can perceive [13]. There are many different ways to measure learning effectiveness [14]. Liu [15] finds that learning effectiveness is an indicator of learning outcomes; learning effectiveness can be assessed by exploring learners' behaviors during different phases of learning [16]. Kintu et al. [17] defines learning outcomes as learning effectiveness, which includes four dimensions: performance, motivation, satisfaction, and knowledge construction. Other indicators of learning effectiveness $[18,19]$ include learner attitudes (including satisfaction and motivation) and post-learning effects (including changes to learning behaviors or improved performance).

The present study measures learning effectiveness by exploring students' leaning behaviors, attitudes, and feelings during classes. These learning behaviors or affects include learners' concentration during lessons, enjoyment in learning, and enthusiasm about the class. Students' learning achievements after completing the class are also used to measure learning effectiveness in the present study. These outcomes include students' comprehension of the instructional content and motivation to continue learning about the topic on their own after completing the class. This section may be divided by subheadings. It should provide a concise and precise description of the experimental results, their interpretation, as well as the experimental conclusions that can be drawn.

\subsection{Factors Impacting Learning Effectiveness}

\subsubsection{Learners' Interactions with Instructors and Classmates}

According to socio-cognitive theories of learning, all learning and teaching activities are social in nature, and knowledge is constructed through social interactions [20]. Astleitner [21] states that learners' interactions with instructors and classmates can contribute to learning effectiveness because learners can exchange messages and ideas, thereby constructing a correct understanding of the content together. Moreover, learners' interaction with instructors and classmates can contribute to the construction of new ideas and knowledge. Hodges et al. [22] contend that learning is a social and cognitive process rather than merely the transfer of information from instructors to learners. A lack of interactions with instructors and classmates could cause learners to withdraw from learning activities 
[21]. Willging and Johnson [23] find that the lack of learner interaction in online courses may lead to failure due to a feeling of isolation. Similarly, Zielinski [24] shows that the lack of interaction among learners contributes to drop-out rates for online courses. Therefore, when developing online courses, it is important to consider both the content and the interactions involved in the learning process [25]. Bernard et al. [25] show that learners' interactions with the instructor and each other lead to improved learning outcomes.

\subsubsection{Learner Engagement in Online Learning Activities}

Learner engagement in online learning activities impacts learning effectiveness as it drives learners to interact with the educational content [26]. To interact with the content, learners must be able to use online devices and the course materials. Coman et al. [5] find that learners' insufficient skills with online devices can reduce the learning effectiveness of online classes. Ferri et al. [27] also find that instructors' and learners' lack of digital skills pose a significant challenge that may hinder learning effectiveness.

\subsubsection{Situational Challenges}

When participating in online learning, learners may face diverse situational challenges. Those include software and hardware errors, disturbances due to the learners' environment such as family activities, and distraction because of possible access to other websites. Many previous studies have found that, when facing failure, different learners react differently and engage in different learning behaviors [28, 29]. Failure in learning tasks could be caused by problems with online platforms or inappropriate learning environments. For instance, Ferri et al. [27] find that inappropriate physical spaces for online learning at home and the activities of other nearby learners can disturb learners' concentration, thus impacting learning outcomes

\subsubsection{Quality of Online Learning Tools}

The quality of online learning tools refers to the functionality of online platforms, which can impact a learner's ability to successfully complete learning tasks. Learners should be able to see media, hear instructions, and respond promptly. In addition, online platforms should function well; this enables learners to continuously pay attention to instructions and learning activities. Loukis, Georgious, and Pazalo [30] find that an online learning platform's quality, reliability, and ease of use contribute to learning effectiveness. Learners' success can be significantly impacted by system functionality [31], and a malfunctioning online system may lead to poor learning effectiveness [32]. Anderson [33] notes that low-quality learning tools and systems with poor response time can hinder learners from achieving learning outcomes. Therefore, it is important to ensure that learning tools and related technology function well during learning and teaching activities.

\section{Scope of the Study}

This study compares the learning effectiveness of face-to-face and online lecture courses. In this study, learning effectiveness refers to learners' learning behaviors or affects during class participation. This includes students' concentration during class, enjoyment in learning, and enthusiasm about the class. In addition, students' learning outcomes after finishing the class are also explored. These outcomes include comprehension of the instructional content and motivation to continue learning about the topic after the class.

This study also analyzes factors that contribute to the learning effectiveness of online instruction. The independent variables include learners' interactions with instructors and classmates, learners' ability to engage in online learning activities, situational challenges, and the quality of online learning tools. The dependent variable is the learning effectiveness of online instruction.

\section{Research Method}




\subsection{Participants}

The participants in this study were bachelor students at King Mongkut's University of Technology Thonburi in Bangkok, Thailand. All participants are studying science and technology. A purposive sampling method was used to select participants; students who registered for an elective, lecture-based social science course, such as history, humans and the environment, or general philosophy, were selected as participants. During the first half of the courses, students met in face-to-face classrooms. Due to the COVID-19 outbreak, the second half of the courses shifted to online learning using both asynchronous and synchronous online platforms. In online learning, students could take part in synchronous online instruction on Zoom or Microsoft Teams. The video recordings of these sessions were also available later; students could access these videos to review the material at any time. A total of 300 students were invited to fill out the survey, and 261 students $(87 \%)$ accepted the invitation. This study was approved by the research ethics committee of the School of Liberal Arts, King Mongkut's University of Technology Thonburi, Thailand.

\subsection{Research Tool and Data Collection}

To measure learning effectiveness, this study explored participants' affects and behavior during and after the class. These include participants' concentration during class, enjoyment in learning, enthusiasm about the class, comprehension of instructional content, and motivation to continue learning about the topic after the class. A five-point Likert scale was used to measure learning effectiveness and most of the independent variables (see Table 1). To measure environmental challenges, participants were asked to indicate whether they experienced specific problems during classes.

Table 1. Questionnaires used for data collection.

\begin{tabular}{|c|c|c|}
\hline Variable & Type of question & Responses \\
\hline \multirow[t]{10}{*}{$\begin{array}{l}\text { Learning } \\
\text { effectiveness }\end{array}$} & $\begin{array}{l}\text { Concentration during participation in a face-to- } \\
\text { face class }\end{array}$ & \multirow[t]{2}{*}{$\begin{array}{l}\text { Very high }=4 \\
\text { Very low }=0\end{array}$} \\
\hline & $\begin{array}{l}\text { Concentration during participation in an online } \\
\text { class }\end{array}$ & \\
\hline & $\begin{array}{l}\text { Comprehension of instructional content from a } \\
\text { face-to-face class }\end{array}$ & \multirow[t]{2}{*}{$\begin{array}{l}\text { Very high }=4 \\
\text { Very low }=0\end{array}$} \\
\hline & $\begin{array}{l}\text { Comprehension of instructional content from } \\
\text { an online class }\end{array}$ & \\
\hline & $\begin{array}{l}\text { Enjoyment in learning during a face-to-face } \\
\text { class }\end{array}$ & \multirow[t]{2}{*}{$\begin{array}{l}\text { Very high }=4 \\
\text { Very low }=0\end{array}$} \\
\hline & Enjoyment in learning during an online class & \\
\hline & $\begin{array}{l}\text { Enthusiasm about learning in a face-to-face } \\
\text { class }\end{array}$ & \multirow[t]{2}{*}{$\begin{array}{l}\text { Very high }=4 \\
\text { Very low }=0\end{array}$} \\
\hline & Enthusiasm about learning in an online class & \\
\hline & $\begin{array}{l}\text { Motivation to continue learning about the topic } \\
\text { after completing a face-to-face class }\end{array}$ & \multirow[t]{2}{*}{$\begin{array}{l}\text { Very high }=4 \\
\text { Very low }=0\end{array}$} \\
\hline & $\begin{array}{l}\text { Motivation to continue learning about the topic } \\
\text { after completing an online class }\end{array}$ & \\
\hline
\end{tabular}




\begin{tabular}{|c|c|c|}
\hline Variable & Type of question & Responses \\
\hline \multirow[t]{2}{*}{$\begin{array}{l}\text { Interaction } \\
\text { with instructor }\end{array}$} & $\begin{array}{l}\text { I1: Learning support from the instructor during } \\
\text { class }\end{array}$ & $\begin{array}{l}\text { Very satisfied }=4 \\
\text { Not satisfied }=0\end{array}$ \\
\hline & $\begin{array}{l}\text { I2: Learning support from the instructor after } \\
\text { class }\end{array}$ & $\begin{array}{l}\text { Very satisfied }=4 \\
\text { Not satisfied }=0\end{array}$ \\
\hline \multirow[t]{2}{*}{$\begin{array}{l}\text { Interaction } \\
\text { with classmates }\end{array}$} & $\begin{array}{l}\text { I3: Learning support from classmates during } \\
\text { class }\end{array}$ & $\begin{array}{l}\text { Very satisfied }=4 \\
\text { Not satisfied }=0\end{array}$ \\
\hline & I4: Learning support from classmates after class & $\begin{array}{l}\text { Very satisfied }=4 \\
\text { Not satisfied }=0\end{array}$ \\
\hline $\begin{array}{ll}\text { Ability } & \text { to } \\
\text { engage } & \text { in } \\
\text { learning } & \\
\text { activities } & \\
\text { during class } & \end{array}$ & I5: Ability to use devices and follow instructions & $\begin{array}{l}\text { Very high }=4 \\
\text { Very low }=0\end{array}$ \\
\hline \multirow{3}{*}{$\begin{array}{l}\text { Quality of } \\
\text { online } \\
\text { platforms and } \\
\text { learning tools }\end{array}$} & $\begin{array}{l}\text { I6: Continuous functionality of the online } \\
\text { platform during class }\end{array}$ & $\begin{array}{l}\text { Very satisfied }=4 \\
\text { Not satisfied }=0\end{array}$ \\
\hline & $\begin{array}{l}\text { I7: Ability to clearly hear the instructor's } \\
\text { explanations }\end{array}$ & $\begin{array}{l}\text { Very satisfied }=4 \\
\text { Not satisfied }=0\end{array}$ \\
\hline & $\begin{array}{l}\text { I8: Ability to see instructional media shown by } \\
\text { the instructor }\end{array}$ & $\begin{array}{l}\text { Very satisfied }=4 \\
\text { Not satisfied }=0\end{array}$ \\
\hline \multirow[t]{4}{*}{$\begin{array}{l}\text { Situational } \\
\text { challenges }\end{array}$} & $\begin{array}{l}\text { I9: Disturbances due to the environment such as } \\
\text { family activities and nuisance from } \\
\text { construction sites. }\end{array}$ & Yes, No \\
\hline & $\begin{array}{l}\text { I10: Distraction because of external factors such } \\
\text { as possible access to other websites and other } \\
\text { attractive acitivities. }\end{array}$ & Yes, No \\
\hline & I11: Learner software errors & Yes, No \\
\hline & I12: Learner hardware errors & Yes, No \\
\hline
\end{tabular}

\subsection{Data Collection and Analysis}

First, the developed questionnaire was validated using the face validity technique. Primary testing of the questionnaire was also conducted with 40 students who were not participants in the study. To test internal consistency, Cronbach's alpha was calculated for the scales used to measure all the study variables. Cronbach's alpha was 0.79, which is higher than the minimum value of 0.7 . Students who registered for a lecture course offered by the School of Liberal Arts at King Mongkut's University of Technology Thonburi in Bangkok, Thailand were asked to participate in this study. The surveys were administered in May and June 2020.

Descriptive statistics were first calculated for the participants' demographic characteristics, including gender, major subject of study, year of study, and current housing situation. Second, paired simple t-tests were performed to test differences in the learning effectiveness of face-to-face and online classes on the same subject. Next, a multiple regression analysis was performed to identify factors that significantly impact the learning effectiveness of online courses. 


\section{Results}

\subsection{Participants Characteristics}

More than half of the participants (56.3\%) were female; $43.7 \%$ were male. Most participants were studying engineering $(63.2 \%)$; $9.6 \%$ of participants were studying technological education, and $8.8 \%$ were studying architecture. The largest cohort, $80.1 \%$, were in their fourth year at the university; $10.7 \%$ were in their third year, and $9.2 \%$ were in their second year. Most participants lived at home (78.5\%); $21.5 \%$ lived in a dormitory (see Table 2). This means that during the national lockdown due to the COVID-19 outbreak, most participants took part in online courses from home.

Table 2. Demographic characteristics of the participants.

\begin{tabular}{|l|l|c|c|}
\hline \multicolumn{2}{|l|}{ Characteristics } & $\mathrm{n}$ & \% \\
\hline \multirow{4}{*}{ Gender } & Male & 114 & 43.7 \\
\cline { 2 - 4 } & Female & 147 & 56.3 \\
\hline \multirow{4}{*}{ Major } & Engineering & 165 & 63.2 \\
\cline { 2 - 4 } & Science and Technology & 48 & 18.4 \\
\cline { 2 - 4 } & Technological Education & 25 & 9.6 \\
\cline { 2 - 4 } & Architecture & 23 & 8.8 \\
\hline \multirow{5}{*}{ School Year } & Second year & 24 & 9.2 \\
\cline { 2 - 4 } & Third year & 28 & 10.7 \\
\cline { 2 - 4 } & Fourth year & 209 & 80.1 \\
\hline \multirow{3}{*}{ Accommodation } & Dormitory & 56 & 21.5 \\
\cline { 2 - 4 } & House & 205 & 78.5 \\
\hline
\end{tabular}

\subsection{Differences in the Learning Effectiveness of Online and Face-to-Face Classes}

The difference in the mean scores for the learning effectiveness of face-to-face and online classes was analyzed using a paired samples t-test (see Table 3). The results revealed that face-to-face learning was significantly more effective than online learning in all aspects. For instance, face-to-face learning led to significantly higher levels of concentration during class $(\mathrm{M}=2.81, \mathrm{SD}=0.84)$ than online learning $(\mathrm{M}=1.87, \mathrm{SD}=0.93)$. The mean score for comprehension of the class content for face-to-face learning $(\mathrm{M}=2.87, \mathrm{SD}$ $=0.80)$ was also significantly higher than that for online learning $(\mathrm{M}=2.29, \mathrm{SD}=0.88)$. Participants also reported higher enjoyment in learning in face-to-face classes $(\mathrm{M}=2.94$, $\mathrm{SD}=0.89)$ than online classes $(\mathrm{M}=1.66, \mathrm{SD}=1.23)$. Face-to-face learning also led to significantly higher levels of enthusiasm about learning $(\mathrm{M}=3.00, \mathrm{SD}=0.84)$ than online learning $(\mathrm{M}=1.48, \mathrm{SD}=1.21)$. Similarly, motivation to continue learning about the topic after completing the class was significantly higher for face-to-face classes $(\mathrm{M}=2.25, \mathrm{SD}=0.72)$ than online classes $(\mathrm{M}=2.26, \mathrm{SD}=0.72)$.

Table 3. Differences in the learning effectiveness of online and face-to-face classes.

\begin{tabular}{|l|c|c|c|c|c|c|c|}
\hline \multirow{2}{*}{ Variables } & \multirow{2}{*}{$\mathrm{n}$} & \multicolumn{2}{c|}{ Online } & \multicolumn{2}{c|}{ Face-to-face } & \multicolumn{2}{c|}{ Statistics } \\
\cline { 5 - 9 } & & $\mathrm{M}$ & $\mathrm{SD}$ & $\mathrm{M}$ & $\mathrm{SD}$ & $\mathrm{t}$ & $\mathrm{p}$ \\
\hline $\begin{array}{l}\text { Concentration during } \\
\text { class }\end{array}$ & 261 & 1.87 & .93 & 2.81 & .84 & $\begin{array}{c}- \\
13.746\end{array}$ & .000 \\
\hline $\begin{array}{l}\text { Comprehension of the } \\
\text { content }\end{array}$ & 261 & 2.29 & .88 & 2.87 & .80 & - & .000 \\
\hline
\end{tabular}




\begin{tabular}{|l|c|c|c|c|c|c|c|}
\hline \multirow{2}{*}{ Variables } & \multirow{2}{*}{$\mathrm{n}$} & \multicolumn{2}{c|}{ Online } & \multicolumn{2}{c|}{ Face-to-face } & \multicolumn{2}{c|}{ Statistics } \\
\cline { 3 - 8 } & $\mathrm{M}$ & $\mathrm{SD}$ & $\mathrm{M}$ & $\mathrm{SD}$ & $\mathrm{t}$ & $\mathrm{p}$ \\
\hline $\begin{array}{l}\text { Enjoyment in learning } \\
\text { during class }\end{array}$ & 261 & 1.66 & 1.23 & 2.94 & .89 & $\begin{array}{c}- \\
13.360\end{array}$ & .000 \\
\hline $\begin{array}{l}\text { Enthusiasm about the } \\
\text { class }\end{array}$ & 261 & 1.48 & 1.21 & 3.00 & .84 & - & 15.698 \\
\hline $\begin{array}{l}\text { Motivation to continue } \\
\text { learning about the topic } \\
\text { after the class }\end{array}$ & 261 & 2.26 & .72 & 2.45 & .72 & -6.862 & .000 \\
\hline
\end{tabular}

\subsection{Factors Impacting the Learning Effectiveness of Online Courses}

The Table 4 shows the descriptive statistics and potential predictors for learning effectiveness. Participants reported relatively low levels of learning effectiveness for online classes. They reported higher scores for interactions with the instructor than for interactions with classmates. They also reported a moderate ability to engage in learning activities during online classes. The mean scores for the quality of online platforms and learning tools used by instructors indicate that participants were quite satisfied with the instructional media used for online learning, as this factor had the highest mean score of the measured variables. However, approximately $25 \%$ of participants reported disturbances caused by the surrounding environment and distraction because of external factors such as possible access to other websites and other attractive activities. Only 12.26\% reported experiencing software errors during online classes, and $11.49 \%$ reported experiencing hardware errors.

Table 4. Descriptive statistics for learning effectiveness and potential predictors.

\begin{tabular}{|c|c|c|c|}
\hline Factor & Variable & $\mathbf{M} / \mathbf{n}$ & $\mathrm{SD} / \%$ \\
\hline \multicolumn{4}{|c|}{ Dependent Variables } \\
\hline \multirow{5}{*}{$\begin{array}{l}\text { Learning } \\
\text { Effectiveness }\end{array}$} & D1: Concentration during class & 1.87 & 0.926 \\
\hline & D2: Comprehension of the instructional content & 2.29 & 0.876 \\
\hline & D3: Enjoyment during class participation & 1.66 & 1.229 \\
\hline & D4: Enthusiasm about the class & 1.48 & 1.214 \\
\hline & $\begin{array}{l}\text { D5: Motivation to continue learning about the } \\
\text { topic after the class }\end{array}$ & 2.26 & 0.717 \\
\hline \multicolumn{2}{|l|}{ Total } & 1.91 & 0.760 \\
\hline \multicolumn{4}{|c|}{ Independent Variables } \\
\hline \multirow[t]{2}{*}{$\begin{array}{l}\text { Interaction } \\
\text { with instructor }\end{array}$} & $\begin{array}{l}\text { I1: Ability to ask the instructor questions during } \\
\text { class if they did not understand the instructional } \\
\text { content }\end{array}$ & 2.46 & 1.065 \\
\hline & $\begin{array}{l}\text { I2: Ability to ask the instructor questions after } \\
\text { class if they did not understand the instructional } \\
\text { content }\end{array}$ & 2.43 & 1.052 \\
\hline $\begin{array}{l}\text { Interaction } \\
\text { with classmates }\end{array}$ & $\begin{array}{l}\text { I3: Ability to discuss content with classmates } \\
\text { during class }\end{array}$ & 2.01 & 1.218 \\
\hline
\end{tabular}




\begin{tabular}{|c|c|c|c|}
\hline Factor & Variable & $\mathbf{M} / \mathbf{n}$ & $\mathrm{SD} / \%$ \\
\hline & $\begin{array}{l}\text { I4: Ability to discuss content with classmates } \\
\text { after class }\end{array}$ & 2.33 & .853 \\
\hline $\begin{array}{l}\text { Ability to } \\
\text { engage in } \\
\text { learning } \\
\text { activities } \\
\text { during the } \\
\text { class }\end{array}$ & $\begin{array}{l}\text { I5: Ability to use devices and follow instructions } \\
\text { during learning activities }\end{array}$ & 2.74 & 0.934 \\
\hline \multirow{3}{*}{$\begin{array}{l}\text { Quality of } \\
\text { online } \\
\text { platforms and } \\
\text { learning tools } \\
\text { used by } \\
\text { instructors }\end{array}$} & $\begin{array}{l}\text { I6: Continuous functionality of the online } \\
\text { platform during class }\end{array}$ & 2.51 & 1.108 \\
\hline & $\begin{array}{l}\text { I7: Ability to hear the instructor's explanations } \\
\text { clearly }\end{array}$ & 2.80 & 1.022 \\
\hline & $\begin{array}{l}\text { I8: Ability to see instructional media shown by } \\
\text { the instructor }\end{array}$ & 3.12 & 0.918 \\
\hline \multirow[t]{4}{*}{$\begin{array}{l}\text { Situational } \\
\text { Challenges }\end{array}$} & $\begin{array}{l}\text { I9: Disturbances due to the environment such as } \\
\text { family activities and nuisance from construction } \\
\text { sites. }\end{array}$ & $66^{*}$ & $25.29 \%$ \\
\hline & $\begin{array}{l}\text { I10: Distraction because of external factors such } \\
\text { as possible access to other websites and attractive } \\
\text { acitivities. }\end{array}$ & $67^{*}$ & $25.57 \%$ \\
\hline & I11: Experiences with software errors & $32^{*}$ & $12.26 \%$ \\
\hline & I12: Experiences with hardware errors & $30^{*}$ & $11.49 \%$ \\
\hline
\end{tabular}

* Number of participants who faced these challenges

Table 5 shows the results of the regression analysis for variables impacting the learning effectiveness of online lecture courses. In the regression analyses, the predictors were the 12 indices, and the criterion variable was learning effectiveness. The results showed that the overall regression model was significant $(F[12,248]=21.075, p=.000)$. The multiple correlation coefficient (R) was .711, and R2 was .505. Therefore, approximately $50.5 \%$ of the variance in learning effectiveness can be accounted for by the linear combination of these 12 independent variables. The variance inflation factor (VIF) ranged from 1.033 to 2.524, which is below the threshold value of 10 [34]. Six variables could significantly predict the learning effectiveness of online classes. Interaction with classmates during class was the most influential $(\beta=0.271)$; this factor was significant at $1 \%$. The ability to discuss content with classmates after class was also significant at $1 \%$, and its beta value was 0.133 . The ability to ask the instructor questions after class was also very influential $(\beta=0.222)$; this factor was significant at $1 \%$. Another important variable was the continuous functionality of the online platform during class, which had a beta value of 0.238 . Participants' ability to use devices and follow instructions was significant at $1 \%$; the beta value for this factor was .123. In addition, disturbances in the surrounding environment significantly and negatively influenced the learning effectiveness of online classes; the beta value for this factor was -0.130 . Learners' facing distraction due to possible access to other websites and other attractive activities was also significant at $5 \%$; its beta value was -0.103 . Other variables had no significant effect on the learning effectiveness of online classes. 
Table 5. Regression analysis for variables impacting the learning effectiveness of online classes (n $=261$ ).

\begin{tabular}{|c|c|c|c|c|}
\hline Variable & B & SE & Beta & VIF \\
\hline $\begin{array}{l}\text { I1: Ability to ask the instructor questions during } \\
\text { class if they did not understand the content }\end{array}$ & .020 & .040 & .028 & 1.546 \\
\hline $\begin{array}{l}\text { I2: Ability to ask the instructor questions after class } \\
\text { if they did not understand the content }\end{array}$ & .160 & .041 & $.222^{* *}$ & 1.649 \\
\hline $\begin{array}{l}\text { I3: Ability to discuss content with classmates during } \\
\text { class }\end{array}$ & .169 & .034 & $271^{* *}$ & 1.447 \\
\hline $\begin{array}{l}\text { I4: Ability to discuss content with classmates after } \\
\text { class }\end{array}$ & .119 & .042 & $.133^{* *}$ & 1.105 \\
\hline I5: Ability to use devices and follow instructions & .100 & .047 & $.123^{*}$ & 1.687 \\
\hline $\begin{array}{l}\text { I6: Continuous functionality of the online platform } \\
\text { during class }\end{array}$ & .163 & .044 & $.238^{* *}$ & 2.027 \\
\hline I7: Ability to hear instructor's explanations clearly & .019 & .053 & .025 & 2.524 \\
\hline $\begin{array}{l}\text { I8: Ability to see instructional media shown by the } \\
\text { instructor }\end{array}$ & -.047 & .056 & -.056 & 2.258 \\
\hline $\begin{array}{l}\text { I9: Disturbances due to the environment such as } \\
\text { family activities and nuisance from construction } \\
\text { sites }\end{array}$ & -.239 & .084 & $-.130 * *$ & 1.045 \\
\hline $\begin{array}{l}\text { I10: Distraction because of external factors such as } \\
\text { possible access to other websites and other } \\
\text { attractive activities }\end{array}$ & -.179 & .081 & $-.103^{*}$ & 1.082 \\
\hline I11: Experiences with software errors & .090 & .128 & .032 & 1.055 \\
\hline I12: Experiences with hardware errors & -.189 & .140 & -.061 & 1.033 \\
\hline $\mathrm{R}$ & \multicolumn{4}{|c|}{.711} \\
\hline R Squared & \multicolumn{4}{|c|}{.505} \\
\hline Adjusted R Squared & \multicolumn{4}{|c|}{.481} \\
\hline $\mathrm{F}$ for change in $\mathrm{R} 2$ & \multicolumn{4}{|c|}{21.075} \\
\hline
\end{tabular}

Note: ${ }^{* *} \mathrm{p}<.01,{ }^{*} \mathrm{p}<.05$

\section{Discussion and Conclusion}

A sudden shift from face-to-face to online learning for lecture courses without proper preparation and management could negatively affect the learning effectiveness of classes. This study revealed that all aspects of learning effectiveness were lower for online classes than face-to-face classes. Students' affects and learning behaviors could be negatively impacted by a sudden change from face-to-face classrooms to an online platform. For instance, students were less motivated to study on their own when taking online classes. Students also reported better comprehension of the content in face-to-face classes. Furthermore, students' concentration reduced when classes shifted to online platforms. Crain and Ragan [35] find that online students' learning performance was poorer than that of students in face-to-face classes. Many studies have found that well-prepared online 
courses that students are trained to use have the same learning effectiveness as face-toface classes. For instance, Bali and Liu [36] find similar learning outcomes for online and face-to-face classes. Neuhauser [37] also show that learning outcomes, such as test and participation scores, are similar for online students and face-to-face students. Therefore, it may be necessary to train learners and instructors to use online platforms to increase the effectiveness of online learning. In addition, online instructors should design online classes which could promote learners' motivation to learn and enhance leaners' enthusiasm about the class.

Several factors affect the learning effectiveness of online instruction. First, the results of the present study show that interactions with classmates during class and interactions with the instructor after class significantly impact learning effectiveness. Interactions with classmates after class also play an important role. These findings align with those of Swan [38], who finds that interactions between the instructor and learners are strongly related to student satisfaction and that interactions among classmates contribute to higher levels of satisfaction with a course. Similarly, Shea [39] reports that interactions among classmates significantly enhance learning effectiveness.

Second, the findings reveal that the quality of online platform, particularly the functionality of the system, significantly influences the learning effectiveness of online courses. Therefore, educational institutes must ensure that the network and system for online courses are well prepared. Loukis, Georgious, and Pazalo [30] find that the quality, reliability, and ease of use of the platform are basic requirements for e-learning and significantly promote learning efficiencyeffectiveness. Anderson [33] finds that poor-quality learning tools and systems with poor response times can hinder learners from achieving learning outcomes.

Third, the results clearly show that learners' abilities to use online devices and follow instructions significantly impact learning effectiveness. Blocker and Tucker [40] explain that students who experience difficulties with technology will have negative attitudes towards online learning. This could lead learners to pay less attention in online courses. Butnaru et al. [41] also find that online learners' learning behaviors and their reactions are impacted by their proficiency with online tools.

Fourth, situational challenges can significantly and negatively influence the learning effectiveness of online classes. These challenges include disturbances caused by learners' environments and a lack of active engagement in class due to distractions caused by the possibility of accessing other websites. These situational challenges may cause students to fail in online learning by reducing their engagement in the course. Ferri et al. [27] also report that activities occurring nearby learners who are participating in an online course could disturb their concentration, thus impacting learning outcomes. Situational challenges can negatively impact students' engagement in an online course. When students fail to engage in the course, learning effectiveness is reduced [42].

In sum, a sudden shift from face-to face to online instruction negatively impacts learning effectiveness. Online learning can also offer many advantages, including enhanced student motivation, a sense of accomplishment, and increased flexibility [43-45], but both instructors and learners must be prepared to use online devices and systems. Most importantly, instructors must design attractive, interesting online courses to engage students' attention. Several points must be considered in the design of online instruction, particularly students' interactions with the instructor and each other. The findings of the present study demonstrate that interactions among classmates during online classes are key to learning effectiveness. Therefore, online learning systems should include channels that allow students to interact with each other, such as platforms for group discussions. The present study also provides evidence of the importance of students' interactions with the instructor after class. Online instructors should therefore plan time for conversations with students after class. In addition, this study has shown that the environments of students in online classes can impact learning effectiveness. Therefore, universities and other educational institutes should provide appropriate on-campus spaces for online learning. 


\begin{abstract}
Author Contributions: P.J. conceived the idea of the study. Both P.J. and S.N. carried out data collection and data analysis. All authors have read and agreed to the published version of the manuscript.

Funding: This research was funded by the School of Liberal Arts, King Mongkut's University of Technology Thonburi, Bangkok, Thailand, and the APC was funded by King Mongkut's University of Technology Thonburi.
\end{abstract}

Acknowledgments: Author would like to acknowledge all participants who involved in questionnaire surveys.

Conflicts of Interest: The author declares no conflict of interest.

\title{
References
}

1. World Health Organization (2020). Health Topics-Coronavrius Disease 2019. Geneva, Switzerland: WHO. Available at: https://www.who.int/health-topics/coronavirus\#tab=tab_1. Accessed March 20, 2021.

2. Akour, A.; Al-Tammemi, A.B.; Barakat, M.; Kanj, R.; Fakhouri, H.N.; Malkawi, A.; Musleh, G. (2020). The Impact of the COVID-19 Pandemic and Emergency Distance Teaching on the Psychological Status of University Teachers: A Cross-Sectional Study in Jordan. Am. J. Trop. Med. Hyg. 103, 2391-2399.

3. Rapanta, C.; Botturi, L.; Goodyear, P.; Guàrdia, L.; Koole, M. (2020). Online university teaching during and after the Covid19 crisis: Refocusing teacher presence and learning activity. Postdigital Sci. Educ. 2, 923-945.

4. García-Alberti, M.; Suárez, F.; Chiyón, I.; Mosquera Feijoo, J.C. (2021). Challenges and Experiences of Online Evaluation in Courses of Civil Engineering during the Lockdown Learning Due to the COVID-19 Pandemic. Educ. Sci. 11, 59.

5. Coman, C.; Țîru, L.G.; Meseșan-Schmitz, L.; Stanciu, C.; Bularca, M.C. (2020). Online Teaching and Learning in Higher Education during the Coronavirus Pandemic: Students' Perspective. Sustainability, 12, 10367.

6. Dhawan, S. (2020). Online Learning: A Panacea in the Time of COVID-19 Crisis. J. Educ. Technol. Syst. 49, 5-22.

7. Marinoni, G.; Van't Land, H.; Jensen, T. (2020). The Impact of COVID-19 on Higher Education around the World. International Association of Universities. Available online:https://www.iauaiu.net/IMG/pdf/iau_covid19_and_he_survey_report_final_may_2020.pdf (accessed on 14 August 2020).

8. Anwar, K.; Adnan, M. (2020). Online learning amid the COVID-19 pandemic: Students perspectives. J. Pedagog. Res. 1, 4551.

9. Suresh, M.; Priya, V.V.; Gayathri, R. (2018). Effect of e-learning on academic performance of undergraduate students. Drug Invent. 10, 1797-1800.

10. Yusuf, N.; Al-Banawi, N. (2013). The Impact of Changing Technology: The Case of E-Learning. Contemp. Issues Educ. Res. 2013, 6, 173-180.

11. Survey on Online and Distance Learning-Results. Available online: https://www.schooleducationgateway.eu/en/pub/viewpoints/surveys/survey-on-online-teaching.htm (accessed on 14 March 2021).

12. Liu, T.L. (2007). The Influence of Teachers' Impression Management Strategy to Students' Learning Satisfaction and Learning Effectiveness in University of Technology - An Example of English Courses in Southern Taiwan University of Technology. Master's Thesis, Southern Taiwan University of Science and Technology, Tainan, Taiwan.

13. Ganesh, G.; Paswan, A.K.; Sun, Q. (2015). Are face-to-face classes more effective than online classes? An empirical examination. Mark. Educ. Rev. 25, 67-81.

14. Hsiang, Y.F. (2011). The Discussion of Outcome Assessment for E-learning Executive Master's Program Student. Master's Thesis, Tamkang University, New Taipei, Taiwan.

15. Liu, H.P. (2002). Study on Learning Satisfaction and Learning Effectiveness of Physical Courses for Senior High School Students in Tainan. Master's Thesis, University of Taipei, Taipei, Taiwan.

16. Snyder, R.A.; Raben, C.S.; Farr, J.L. (1980). A model for the systemic evaluation of human resource development programs. Acad. Manag. Rev. 5, 431-444.

17. Kintu, M. J.; Zhu, C.; Kagambe, E. (2017). Blended learning effectiveness: the relationship between student characteristics, design features and outcomes. 1. International Journal of Educational Technology in Higher Education (2017) 14:7.

18. Guay, F.; Ratelle, C.F.; Chanal, J. (2008). Optimal learning in optimal contexts: The role of self-determination in education. Can. Psychol. 49, 233.

19. Pike, G.R.; Smart, J.C.; Ethington, C.A. (2012).The mediating effects of student engagement on the relationships between academic disciplines and learning outcomes: An extension of Holland's theory. Res. High. Educ. 53, 550-575.

20. Harasim, L. (1990). On-line Education: Perspectives on a New Environment. New York: Praeger

21. Astleitner, H. (2000). Dropout and distance education. A review of motivational and emotional strategies to reduce dropout in web-based distance education. In Neuwe Medien in Unterricht, Aus-und Weiterbildung Waxmann Munster, New York.

22. Hodges, C.; Moore, S.; Lockee, B.; Trust, T.; Bond, A. (2020). The difference between emergency remote teaching and online learning. Educ. Rev. Available online:https://er.educause.edu/articles/2020/3/the-difference-between-emergency-remoteteaching-and-online-learning (accessed on 10 April 2021). 
23. Willging, P. A., \& Johnson, S. D. (2009). Factors that influence students' decision to drop-out of online courses. Journal of Asynchronous Learning Networks, 13(3), 115-127.

24. Zielinski, D. (2000). Can you keep learners online? Training, 37(3), 64-75.

25. Bernard, R.M.; Abrami, P.C.; Borokhovski, E.; Wade, C.A.; Tamim, R.M.; Surkes, M.A.; Bethel, E.C. (2009). A meta-analysis of three types of interaction treatments in distance education. Rev. Educ. Res. 79, 1243-1289.

26. Swan, K. (2003). Learning effectiveness: what the research tells us. In J. Bourne \& J. C. Moore (Eds) Elements of Quality Online Education, Practice and Direction. Needham, MA: Sloan Center for Online Education, 13-45.

27. Ferri, Fernando, Patrizia Grifoni, and Tiziana Guzzo. (2020). Online Learning and Emergency Remote Teaching: Opportunities and Challenges in Emergency Situations. Societies, 10, no. 4: 86.

28. Diener, C.I.; Dweck, C.S. (1978). An analysis of learned helplessness: Continuous changes in performance, strategy, and achievement cognitions following failure. J. Pers. Soc. Psychol. 36, 451.

29. Diener, C.I.; Dweck, C.S. (1980). An analysis of learned helplessness: II. The processing of success. J. Pers. Soc. Psychol. 39, 940.

30. Loukis, E., Georgiou, S. \& Pazalo, K. (2007). A value flow model for the evaluation of an e-learning service. ECIS, 2007 Proceedings, paper 175.

31. Pituch, K. A., \& Lee, Y. K. (2006). The influence of system characteristics on e-learning use. Computers \& Education, 47(2), $222-244$.

32. Anderson, T. (2004). Theory and Practice of Online Learning. Canada: AU Press, Athabasca University.

33. Shrain, K. (2012). Moving towards e-learning paradigm: Readiness of higher education instructors in Palestine. International Journal on E-Learning, 11(4), 441-463.

34. Field, A. P. (2009). Discovering statistics using SPSS: And sex and drugs and rock " $\mathrm{n}$ " roll (3rd ed.). London, England: SAGE.

35. Crain, S., \& Ragan, K. (2017). Online Versus Face-to-Face Course Learning Effectiveness: Measured Outcomes for Intermediate Financial Management. Journal of Financial Education, 43(2), 243-261.

36. Bali, S.; Liu, M. (2018). Students' perceptions toward online learning and face-to-face learning courses. J. Phys. Conf. Ser.1108, 012094.

37. Neuhauser, C. (2002). Learning Style and Effectiveness of Online and Face-to-Face Instruction the American Journal of Distance Education, 16(2), 99-113.

38. Swan, K. (2001). Virtual interactivity: design factors affecting student satisfaction and perceived learning in asynchronous online courses. Distance Education, 22(2), 306-331.

39. Shea, P. J., Swan, K., Fredericksen, E. E \& Pickett, A. M. (2002). Student satisfaction and reported learning in the SUNY Learning Network. In J. Bourne \& J. C. Moore (Eds) Elements of Quality Online Education, Volume 3. Olin and Babson Colleges: Sloan Center for Online Education.

40. Blocker, J. M., \& Tucker, G. (2001). Using constructivist principles in designing and integrating online collaborative interactions. In F. Fuller \& R. McBride (Eds.), Distance education. Proceedings of the Society for Information Technology \& Teacher Education International Conference (pp. 32-36). ERIC Document Reproduction Service No. ED 457822.

41. Butnaru, G.I.; Nit, `a, V.; Anichiti, A.; Brînz `a, G. (2021). The Effectiveness of Online Education during Covid 19 PandemicA Comparative Analysis between the Perceptions of Academic Students and High School Students from Romania. Sustainability, 13, 5311.

42. Nurmela K., Palonen T., Lehtinen E., Hakkarainen K. (2003). Developing Tools for Analyzing CSCL Process. In: Wasson B., Ludvigsen S., Hoppe U. (eds) Designing for Change in Networked Learning Environments. Computer-Supported Collaborative Learning, vol 2. Springer, Dordrecht.

43. Zahrani, H.A.; Laxman, K. (2016). A critical meta-analysis of mobile learning research in higher education. J. Tech. Stud. 42, 2-17.

44. Hiltz, S.R.;Wellman, B. (1997). Asynchronous learning networks as a virtual classroom. Commun. ACM, 40, 44-49.

45. Hwang, G.J.; Wu, P.H. (2012). Advancements and trends in digital game-based learning research: A review of publications in selected journals from 2001 to 2010. Br. J. Educ. Technol. 43, E6-E10. 